\title{
Knowledge arising from long-term research of variable retention harvesting in Tierra del Fuego: where do we go from here?
}

\author{
Guillermo J. Martínez Pastur ${ }^{1 *} \mathbb{D}$, Yamina M. Rosas ${ }^{1}$, Mónica Toro Manríquez $^{1}$, Alejandro Huertas Herrera', \\ Juan A. Miller ${ }^{1}$, Juan M. Cellini ${ }^{2}$, Marcelo D. Barrera ${ }^{2}$, Pablo L. Peri ${ }^{3}$ and María V. Lencinas ${ }^{1}$
}

\begin{abstract}
Nothofagus pumilio forests in Tierra del Fuego are the southernmost forests in the world, where extreme climate conditions represent a challenge to attain sustainable forest management. Retention forestry was proposed as an alternative to increase the species conservation in managed stands. Here, we synthetized results related to the implementation of a variable retention harvesting based on a combination of aggregate patches and dispersed retention during the last 18 years comparing with other silviculture proposals (e.g., shelterwood cuts) and control treatments (primary unmanaged forests). We summarized the results for (i) sawmill operations, (ii) timber yield, (iii) overstory stability, (iv) forest structure, (v) microclimate and natural cycles, (vi) natural regeneration dynamics (flowering, seeding, foraging, recruitment, growth, and mortality), and (vii) biodiversity (mammals, understory plants, mistletoes, birds, arthropods, mosses, lichens, and fungi). In general, aggregate patches maintained forest structure and micro-environmental variables, and slightly increased biodiversity and forest reproduction variables compared to unmanaged primary forests. On the contrary, dispersed retention decreased forest structure variables and greatly increased biodiversity (richness and abundance) when it was compared to unmanaged primary forests. Ecological conditions are influenced by variable retention harvesting, but direction and magnitude of the effect depend and differ according to retention types. Besides this, biodiversity taxa greatly differed among groups depending on retention types. In general, the species assemblages in aggregate patches were similar to those found in primary unmanaged forests, while they were significantly modified in the dispersed retention. This occurred due to (i) local extinction of some original species, (ii) the introduction of native species from the surrounding environments, or (iii) the invasion of exotic species. This silvicultural method has been a useful tool to conserve biodiversity and ecosystem functions, approaching to the balance between economy, ecology, and social requirements in the managed areas.
\end{abstract}

Keywords: Aggregate patches, Dispersed retention, Biodiversity conservation, Long-term sustainability, Timber production

\section{Background}

The preservation of native forests should be one of the most important goals in forest management to preserve biodiversity and the multiple goods and ecosystem services that they provide (Kozlowski 2002; Perera et al. 2018). The demands upon forest resources grow with the increasing

\footnotetext{
* Correspondence: gpastur@conicet.gov.ar

${ }^{1}$ Centro Austral de Investigaciones Científicas (CADIC), Consejo Nacional de Investigaciones Científicas y Técnicas (CONICET), Houssay 200 (9410), Ushuaia, Tierra del Fuego, Argentina

Full list of author information is available at the end of the article
}

world population, especially in the less populated and forested areas (Lindenmayer 1999). This pressure produces a mismanagement of forests in many regions as result of inappropriate social and political decisions (Gea et al. 2004), e.g., degradation due to over-grazing, conversion to plantations or croplands. Ecologically sustainable forest management was proposed all around the world as a solution to many ecological and socio-economic problems associated with forest uses, where the differences between theory to practice is the major challenge (Perera et al. 2018). Ecologically sustainable forest management is defined as a 
forest management that perpetuates ecosystem integrity while providing wood and non-wood values; where ecosystem integrity means the maintenance of forest structural complexity, species diversity and composition, and ecological processes and functions within the bounds of normal disturbance regimes (Lindenmayer et al. 2012).

The preservation of a percentage of the ecosystems in natural reserves is proposed as one alternative to protect biodiversity and ecosystem services provision (land-sparing strategy), but fails to protect the species survival at landscape level (Lindenmayer et al. 2006; Phalan et al. 2011). In example, forest plantations and intensive managed stands had lower richness and abundance than the original species assemblage of the primary unmanaged forests (Deferrari et al. 2001; Spagarino et al. 2001; Martínez Pastur et al. 2002). For this, variable retention harvesting is proposed as one alternative to increase species conservation at landscape level (land-sparing strategy) that includes the managed forests (Franklin and Forman 1987; Franklin et al. 1997; Mitchell and Beese 2002; Lindenmayer et al. 2019). This alternative was proposed to create middle-scale reserves (e.g., conservation of some patches of unaltered natural environments) and left forest-legacies in the harvested areas (e.g., live and dead trees, stumps, rotten wood, roots of harvested trees, shrubs, and understory plants) (Lindenmayer et al. 2012). The implementation of this concept varied according to forest policies of each country or region (see appendix of Gustafsson et al. 2012).

The variable retention harvesting was proposed as an alternative to increase the species conservation in managed stands in Tierra del Fuego forests (Argentina). Here, we synthetized results related to the implementation of a variable retention method based on a combination of aggregate patches and dispersed retention during the last 18 years comparing with other silviculture proposals (e.g., shelterwood cuts) and control treatments (primary unmanaged forests). We summarized the results for (i) sawmill operations, (ii) timber yield, (iii) overstory stability, (iv) forest structure, (v) microclimate and natural cycles, (vi) natural regeneration dynamics (flowering, seeding, foraging, recruitment, growth, and mortality), and (vii) biodiversity (mammals, understory plants, mistletoes, birds, arthropods, mosses, lichens, and fungi). We want to answer the following questions: (i) variable retention harvesting presents advantages compared to other silvicultural proposals, (ii) how much of the services provided for primary unmanaged forests were maintained with the variable retention harvesting, (iii) proposed aggregate patch size is enough to maintain most of the original conditions in the managed stands, (iv) is it economically feasible the implementation of the variable retention harvesting, and (v) is it possible to make actionable recommendations or best management practices to improve the harvesting in these forests based on the obtained results?

\section{Nothofagus forests in Tierra del Fuego and human uses along the history}

Tierra del Fuego landscapes were modeled by glaciers, and after the definitive ice-retreat (10 ka years ago), vegetation changed from tundra and cold steppes to Sub-Antarctic forested environments (Rabassa et al. 2000). Human colonization occurred between 11.0 and 6.4 ka years ago, and these first inhabitants of the archipelago used the forests for shelter, hunting, food, construction wood materials (e.g., canoes), and firewood (Tivoli and Zangrando 2011). Europeans starting the colonization in the late nineteenth century where harvesting for timber and firewood continue to date (Gea et al. 2004; Gamondés Moyano et al. 2016). The colonization produced greatest changes in these forests, due to (i) extermination of original inhabitants, (ii) introduction of large quantities of domestic herbivores (e.g., sheep and cattle) that compete with local Lama guanicoe populations, and (iii) the impact of exotic species over the natural ecosystems, including several plants species, insects (e.g., Vespula germanica), and mammals (e.g., Castor canadensis) (Gea et al. 2004; Luque et al. 2010; Lencinas et al. 2012; Sola et al. 2015; Huertas Herrera et al. 2018). Intensive harvesting of the native forest started in the middle of the twentieth century with the increase of human population, mainly for the sawmill industry. Considering the initial forest cover, near $6 \%$ was transformed into grasslands for ranching, 5\% in meadows by beavers, $27 \%$ was employed for cattle or sheep breeding, $12 \%$ was intensively harvested and then recovered as secondary forests, and the other half of these forests remained unaltered in their structure with a relative good conservation of their original biodiversity assemblage.

\section{Species assemblage in Nothofagus forested landscapes}

Nothofagus forested landscapes are conformed by intermixed patches of forests, grasslands, peatlands, and shrublands, extended from the sea level to 650 m.a.s.l. where tree-line occurred. Timber forests are mainly composed of Nothofagus pumilio (Martínez Pastur et al. 2000). This native tree is a medium shade intolerant species, growing in pure or mixed stands with Nothofagus betuloides. Natural regeneration grows abundantly, mostly in gap dynamics, which creates an uneven age structure in an irregular patchy distribution (Gea et al. 2004; Martínez Pastur et al. 2011a, b). These forested landscapes present a low species richness because of the extreme climatic conditions, due to the low latitude (54-55 $\mathrm{S}$ ) and the short growing season (4-5 months), e.g., tree-ring was forming in just 2 months between December and February (Massaccesi et al. 2008). Timber forest landscapes of central Tierra del Fuego presented (i) 100 plant and fern species (> 30\% were adventives), 
(ii) 30 bird species, (iii) more than 500 arthropod species (three identified exotic species), (iv) 12 mammals (more than half were exotic), and (v) an unknown number of other less studied groups (e.g., mosses, liverworts, lichens, fungi) (Lencinas et al. 2005, 2008a, b).

Biodiversity changes across the landscape, where most of the species are generalist and live across the landscape. However, some species only occur in specific environments, and are sensitive to environmental changes as harvesting (e.g., ferns, lichens, and many arthropods) (Lencinas et al. 2005, 2008a, b; Huertas Herrera et al. 2018). Forests present special features that favor some species (e.g., woodpeckers, coleopterons, hymenopterons, dipterons, pseudoscorpions, ferns, mistletoes, mosses, and lichens) due to offer food (e.g., Cerambicidae larvae in rotten wood for Campephilus magellanicus) or shelter during winter (e.g., forest floor not frozen at $20 \mathrm{~cm}$ depth along the round year, allowing the survival of several species in the coldest months) (Table 1). These species assemblages varied according to vegetation type or across site quality gradients (Lencinas et al.
2005, 2008a, b; Gallo et al. 2013), e.g., some species only occur in timber forests (e.g., Viola magellanica and Dysopsis glechomoides, or birds that need large trees to foraging and nesting such as Campephilus magellanicus) (Lencinas et al. 2005, 2008a). For this, each vegetation type is important for the conservation planning, as well as the timber forests due to its particular species assemblage (Luque et al. 2010; Martínez Pastur et al. 2013b, 2016a; Huertas Herrera et al. 2018).

\section{Silviculture implemented in Nothofagus pumilio forests: the raise of the variable retention harvesting}

The traditional management was mainly proposed to convert primary uneven forests conformed by patches of different ages (from seedlings to 450-year-old trees) into secondary managed stands with a rotation length of 70 120 years depending of site quality and silviculture treatments (Gea et al. 2004; Martínez Pastur et al. 2013b). These proposals promote the total removal of the original forest structure, e.g., clear-cuttings was prescribed in 40

Table 1 Trends of change of biodiversity comparing primary unmanaged forests with different retention types during the first 10 years after harvesting in Nothofagus pumilio forests ( $A R=$ aggregate patches, DR $=$ dispersed retention) and associated nontimber landscapes (N. antarctica forests and openlands) in Tierra del Fuego

\begin{tabular}{|c|c|c|c|c|c|}
\hline Group & Sub-group & $\mathrm{AR}$ & DR & Landscape & References \\
\hline Mammals & Guanaco & + & ++ & +++ & Soler et al. 2012; Martínez Pastur et al. 2016b \\
\hline \multirow[t]{4}{*}{ Birds } & Passeriformes & + & +++ & +++ & \multirow[t]{4}{*}{ Lencinas et al. 2005, 2009, 2018; Soler et al. 2015, 2016; Vergara and Schlatter 2006} \\
\hline & Raptors & + & +++ & +++ & \\
\hline & Woodpecker & $=$ & -- & - & \\
\hline & Others & $=$ & + & + & \\
\hline \multirow[t]{7}{*}{ Arthropods } & Coleopterons & -- & --- & - & \multirow{7}{*}{$\begin{array}{l}\text { Lencinas et al. 2008b, 2010, 2012, 2014, 2015, 2017; Simanonok et al. 2011; Soler et al. 2015, } \\
2016\end{array}$} \\
\hline & Hymenopterons & -- & -- & -- & \\
\hline & Dipterons & - & -- & -- & \\
\hline & Lepidopterons & $=$ & - & $=$ & \\
\hline & Other insects & -- & -- & + & \\
\hline & Spiders & -- & -- & + & \\
\hline & Pseudoscorpions & $=$ & - & - & \\
\hline \multirow[t]{5}{*}{ Plants } & Dicots & + & +++ & ++ & \multirow[t]{5}{*}{ Lencinas et al. 2008a, 2011, 2017; Soler et al. 2014, 2015, 2016; Martínez Pastur et al. 2016a } \\
\hline & Monocots & + & +++ & +++ & \\
\hline & Ferns & $=$ & -- & - & \\
\hline & Adventive & + & +++ & ++ & \\
\hline & Mistletoes & +++ & ++ & -- & \\
\hline Mosses & $\begin{array}{l}\text { Understory } \\
\text { mosses }\end{array}$ & $=$ & + & - & Lencinas et al. 2008c; Soler et al. 2015, 2016 \\
\hline Lichens & Epiphytic lichens & -- & --- & - & Soler et al. 2014, 2015, 2016 \\
\hline \multirow[t]{2}{*}{ Fungi } & Phylloplane & $=$ & + & $?$ & \multirow[t]{2}{*}{ Ducid et al. 2005; Hewitt et al. 2018} \\
\hline & Mycorrhizae & $=$ & -- & $?$ & \\
\hline
\end{tabular}


50-m-wide strips, as well as shelterwood cuts in two-stages (first cut leaving $30 \mathrm{~m}^{2}$ basal area and a final cut that removes the remaining trees after 10-20 years) (Martínez Pastur et al. 2000). These silviculture methods were successfully applied in several temperate forests around the world, both using natural regeneration and combined with some plantation of target species (Gustafsson et al. 2012; Frelich et al. 2015; Donoso et al. 2019). These silvicultural methods were successfully applied in Nothofagus forests for many years, where harvested stands quickly recovered after cuts through the abundant natural regeneration (Martínez Pastur et al. 2011a, b). The following interventions (thinning and pruning) increased the growth rate and timber quality of the selected trees (Peri et al. 2002, 2013). However, the sawmill industry in Southern Patagonia was designed to process only the best quality logs, leading to high-grading cuttings, and leaving an economic degraded forests with uncompleted treatments prescriptions (e.g., first cuts of the shelterwood were implemented in 50,000 ha but final cuts were never applied) (Gea et al. 2004; Martínez Pastur et al. 2007a). This trade-off greatly influenced the management in Southern Patagonia, mainly due to the distance to markets, and defined the main difference with other temperate forests where the closeness of the markets led to intensive harvesting (Donoso et al. 2019; Soman et al. 2019).

The local forest regulations in Southern Patagonia promote the conservation of a large percentage of the native forests, where producers must compulsorily protect them avoiding any kind of silvicultural intervention. These regulations include two strategies that generate a medium-scale protection: (i) national law 26.331/07 protect forests with special conservation features despite the ownership status (state or private lands) (Gamondés Moyano et al. 2016; Martínez Pastur et al. 2016a); and (ii) provincial law 145/94 request that forest management plans avoid interventions in stands with environmental protection role (e.g., riversides, high slopes, edges with open lands or forest growing above 400 m.a.s.l.) or with low site qualities (e.g., forests below $15 \mathrm{~m}$ dominant height) (Martínez Pastur et al. 2000). Harvesting only removes timber logs for sawmill industry (e.g., up to $20 \mathrm{~cm}$ with $<30 \%$ of rotten wood, representing $13-20 \%$ of the total live biomass), and left root systems (40-50\%), crowns (branches and leaves) (18\%), stumps (2\%), as well as the standing dead trees and deadwood in the forest floor (17-20\%) (Peri et al. 2008; Martínez Pastur et al. 2000, 2009). Besides this, low quantities of firewood were also removed from these harvested areas, but decreased on time due to natural gas being available in most urban and rural areas since 1970 (Gea et al. 2004).

Recently, new harvesting proposals had been demanded for $N$. pumilio forests due to (i) incomplete implementation of shelterwood cut prescriptions, and large quantities of wood material remaining in the harvested areas (Martínez Pastur et al. 2000, 2009); (ii) the need to improve the land-sparing strategies at stand level due to local species extinction (Deferrari et al. 2001; Spagarino et al. 2001; Martínez Pastur et al. 2002); and (iii) the social concern about the forest management (Gamondés Moyano et al. 2016). The variable retention was firstly proposed by some private ranch (e.g., San Justo, Los Cerros, and Campo Chico) (Fig. 1) and sawmill (e.g., Los Castores, Fregosini Hnos, and Kareken) ownerships, and it was formally included in forest management plans since 2001 to date. The proposal includes a combination of aggregate patches (60 $\mathrm{m}$ diameter, one per hectare) and dispersed retention (10-15 $\mathrm{m}^{2} \mathrm{ha}^{-1}$ between aggregate patches) in timber forests (40-50\% of the aboveground biomass), as well as the protection of those forests preserved by local regulations that was listed before (30-50\% of the total forest cover) (Martínez Pastur et al. 2013b). This proposal improves the harvesting and decreases the costs: (i) the oriented cuts are mandatory for chainsaw operators, who must avoid fall-down trees inside the aggregate patches, and (ii) the extraction paths of skidders are fixed every $100 \mathrm{~m}$ avoiding the aggregate patches, increasing extraction rates and decreasing soil damage (Martínez Pastur et al. 2007a) (Fig. 2). The retention percentage and pattern varied according to the different countries and management objectives, and were regulated according to the forest policies (Gustafsson et al. 2012), e.g., in public lands of Tasmania they retain $30 \%$ of the cutting area, in public and private lands of Estonia, Finland, Germany, Latvia, Lithuania, and Norway less than $10 \%$ is required, and North America varied between 1 and $20 \%$.

\section{Yield and forest structure dynamics}

The retention percentage between a variable retention proposal and the first cut of the shelterwood cut system is similar in terms of basal area (near $30 \mathrm{~m}^{2} \mathrm{ha}^{-1}$ ) but differs in the spatial distribution pattern across the harvested stand, e.g., homogeneous distribution in the shelterwood cuts, and aggregate patches $(2 / 3)$ and dispersed trees $(1 / 3)$ in the variable retention. Besides this, the yield (quantity, size, or quality logs) does not significantly vary between both proposals along a full site quality gradient (Martínez Pastur et al. 2009), e.g., $165.4 \mathrm{~m}^{3} \mathrm{ha}^{-1}$ in shelterwood cuts and $164.9 \mathrm{~m}^{3} \mathrm{ha}^{-1}$ in variable retention. For this, producers implement the variable retention harvesting mainly because most of them never realize the final cuts of the shelterwood system (Martínez Pastur et al. 2000, 2007a).

During harvesting, many trees were damaged (mainly in the tree base and root system), increasing the tree fall-down during the first years after harvesting, e.g., remnant basal area in shelterwood cuts is reduced in 


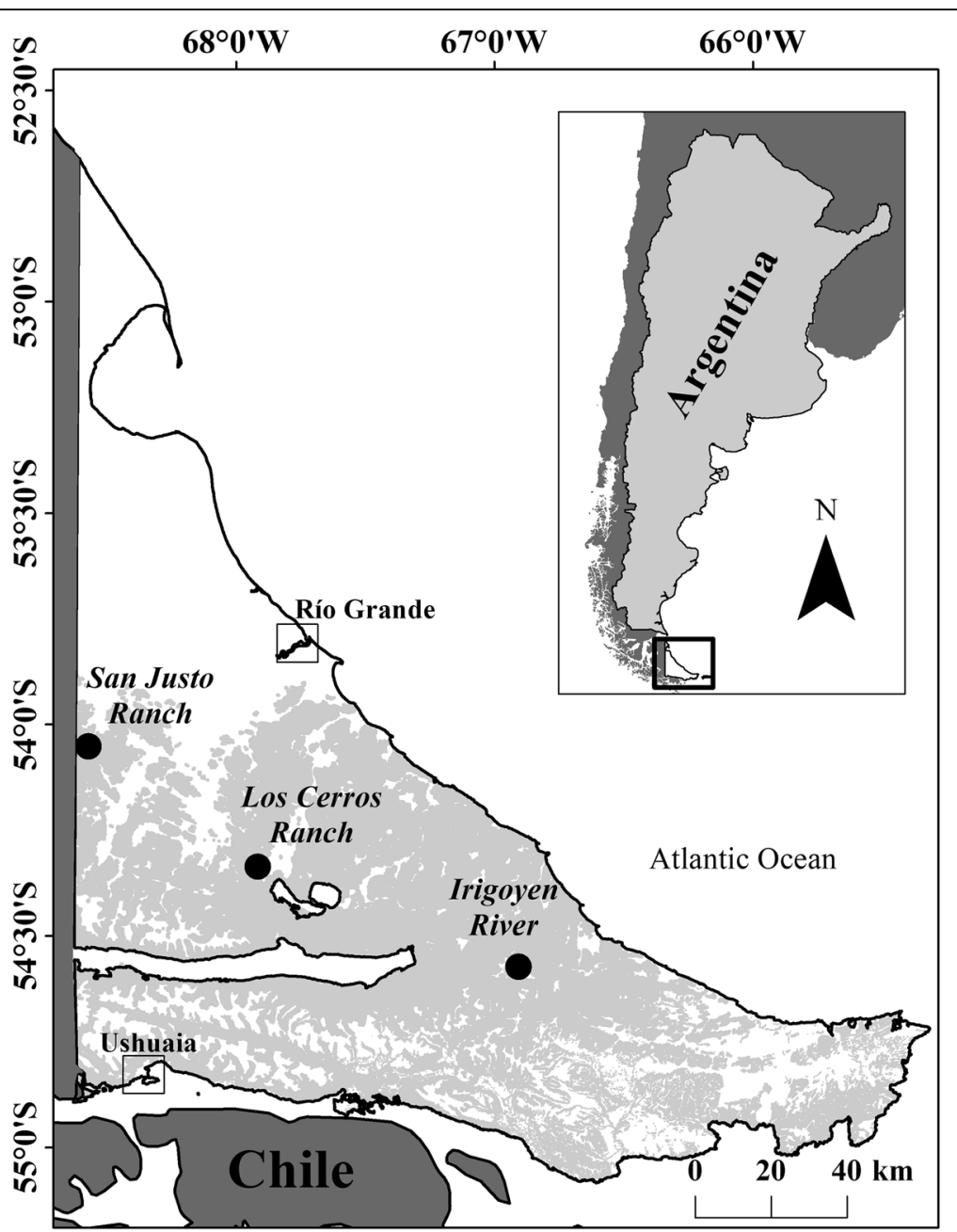

Fig. 1 Location of the variable retention long-term studies (black dots) at the main localities (empty squares) distributed in the regional gradient of the natural distribution of Nothofagus forests in Tierra del Fuego (Argentina)

50\% (Martínez Pastur et al. 2000; Cellini et al. 2013). Variable retention decreases these damages because (i) aggregate patches had been protected during harvesting (no roads, no cuts inside or near them), and (ii) road design between aggregate patches decreases the skidder movements in the managed stands. Besides this, wind-blown of many trees naturally occurred in the managed stands due to wind modeled the landscape as natural driver of change of the forest structure (Rebertus et al. 1997). In one of the long-term studies located in Los Cerros Ranch (see PEBANPA network in Peri et al. 2016), a monitoring was conducted over 72 plots (Fig. 1 and Table 2). After harvesting, aggregate patches presented a similar basal area (average \pm standard deviation, $75.0 \pm 17.8 \mathrm{~m}^{2} \mathrm{ha}^{-1}$ ) to primary unmanaged forests $\left(73.9 \pm 15.4 \mathrm{~m}^{2} \mathrm{ha}^{-1}\right)$. The basal area in the dispersed retention varied according to the influence of the aggregate patches, being greater near the influence area around the aggregate patches $\left(20.0 \pm 11.0 \mathrm{~m}^{2} \mathrm{ha}^{-1}\right)$ than outside the influence of the aggregate patches $(10.5 \pm$ $10.3 \mathrm{~m}^{2} \mathrm{ha}^{-1}$ ). The remnant basal area at stand level considering both retention types was $34.6 \mathrm{~m}^{2} \mathrm{ha}^{-1}$. After 15 years, the basal area of the aggregate patches was reduced by $32 \%$ mainly in the edges, while the dispersed retention was reduced by $13 \%$. Besides this, the remnant basal area at stand level considering both retentions reached to $28.7 \mathrm{~m}^{2} \mathrm{ha}^{-1}$. This stability was greater at stand level than the first cuts recorded for shelterwood cuts (Cellini et al. 2013). The basal area not only decreased for the wind-throws associated to the skidder damages but also decreased due to dieback of the isolated mature trees (dryness do to wind exposure) which was observed along the studied years in the long-term plots (up to 18 years after harvesting). Besides this, some 


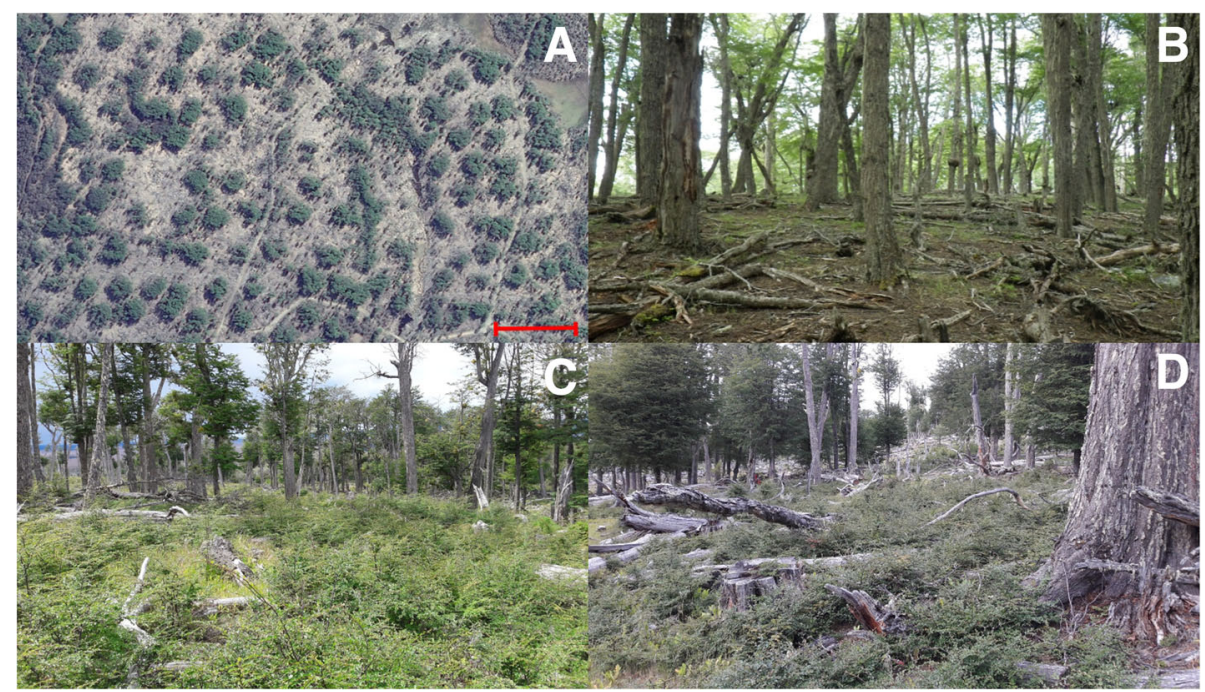

Fig. 2 Variable retention harvesting in Nothofagus pumilio forests in Tierra del Fuego Argentina. a Google Earth image $\left(54^{\circ} 22^{\prime} 51^{\prime \prime} \mathrm{S}, 67^{\circ} 51^{\prime} 45^{\prime \prime}\right.$ W) in harvested stands 12 years after harvesting (2017) (red bar represent $200 \mathrm{~m}$ ). b Primary unmanaged stand during the summer season. c, d Harvested areas with established regeneration 14 years after harvesting (2019) in areas with aggregate patches and dispersed retention

trees favorably reacted to the canopy openings, mainly young trees $(<150$ years old $)$ that usually occupied the intermediate or co-dominant strata in the primary forests. The increment in growth volume can reach up to $20 \%$ at individual level (Gea et al. 2004). However, crown cover did not follow the same pattern than basal area (see methodology and data taking in Martínez Pastur et al. 2011a, b), which can increase and decrease along the years. Thus, while primary unmanaged forests presented slight variations $(86.5 \pm 0.8 \%)$ along the years, the aggregate patches showed lower values than primary unmanaged forests due to the closeness of the harvesting $(76.5 \pm 0.9 \%)$, where minimum values were recorded 10 years after harvesting, but which partially recovered in the subsequent years. Similar trend was observed in the dispersed retention $(49.3 \pm 1.9 \%$ and $40.8 \pm 2.4 \%$ close and far away to aggregate patches, respectively), where minimum values were recorded 8-10 years after harvesting and partially recovered in the following years. It is possible to conclude that positive synergies occur between aggregate patches and dispersed retention, where both retention types allow maintaining the forest structure of the theoretical silvicultural models (Martínez Pastur et al. 2013b).

\section{Microclimate and natural cycles}

Soil moisture and solar radiation are the main factors affecting the regeneration and understory dynamics, and also can be associated to biodiversity changes (Martínez Pastur et al. 2011a; Lencinas et al. 2017) (Table 2). Rainfall is a limiting factor during middle summer, where overstory canopy retains $25 \%$; $50 \%$ is lost as edaphic evapotranspiration, and less than $20 \%$ is lost as soil percolation (Frangi and Richter 1994). This phenomenon maintains rainfall pattern across the year, generating a low soil moisture availability under closed canopies (e.g., soil water content during middle summer was $21 \pm 9 \%$ in primary unmanaged forests and $23 \pm 11 \%$ in aggregate patches). When the canopy is open, the effective rainfall that reaches the forest floor greatly changed (Caldentey et al. 2005), e.g., in the dispersed retention reached to $48 \pm 15 \%$ under the influence of the aggregate patches and $37 \pm 10 \%$ without the influence of the aggregate patches (Martínez Pastur et al. 2011b). Temperature, wind, and solar radiation are also directly related to the canopy cover (Caldentey et al. 2009; Martínez Pastur et al. 2011a, b, 2013b, 2014). The overstory acts as a temperature regulator, where maximum temperatures during summer and minimum during winter occur in the harvested areas. Soil does not freeze at $20 \mathrm{~cm}$ depth during winter under closed canopies (e.g., primary unmanaged forests and aggregate patches), and frost damages in the regeneration are higher in the dispersed retention during spring and early summer. Wind effect is low under closed canopy cover, leading to low losses due to evapotranspiration in seedlings and saplings (Tíscar 2019; Hankin et al. 2019). Finally, solar radiation during the growing season is directly related to canopy closure, and limits understory and regeneration development. The aggregate patches presented similar solar radiation values to primary unmanaged forests (7.7 \pm $1.8 \mathrm{~W} \mathrm{~m}^{-2}$ compared to $6.3 \pm 0.7 \mathrm{~W} \mathrm{~m}^{-2}$ ), and these values 
Table 2 Trends of change of forest and environment variables comparing primary unmanaged forests with different retention types during the first 10 years after harvesting ( $A R=$ aggregate patches, $D R=$ dispersed retention) in Nothofagus pumilio forests in Tierra del Fuego

\begin{tabular}{|c|c|c|c|c|}
\hline Group & Sub-group & $A R$ & DR & References \\
\hline \multicolumn{5}{|l|}{ Forest } \\
\hline \multirow[t]{6}{*}{ Reproduction } & Seed production & - & --- & Martínez Pastur et al. 2008, 2011a, b, 2013a, b, 2014, 2016a, b; Soler et al. 2015; Torres et al. 2015 \\
\hline & Recruitment & + & -- & \\
\hline & Survival & + & +++ & \\
\hline & Growth & + & +++ & \\
\hline & Browsing & + & +++ & \\
\hline & Abiotic damage & $=$ & - & \\
\hline \multirow[t]{6}{*}{ Structure } & Stability & - & --- & Martínez Pastur et al. 2007a, 2009, 2013b; Cellini et al. 2013; Soler et al. 2015 \\
\hline & Dieback & + & ++ & \\
\hline & Growth & + & +++ & \\
\hline & Crown cover & - & -- & \\
\hline & Litter production & - & --- & \\
\hline & Dead-wood & $=$ & ++++ & \\
\hline \multicolumn{5}{|l|}{ Environment } \\
\hline \multirow[t]{7}{*}{ Microclimate } & Rainfall & + & +++ & Martínez Pastur et al. 2011a, b, 2013b, 2014 \\
\hline & Max air temp & $=$ & ++ & \\
\hline & Min air temp & $=$ & -- & \\
\hline & Max soil temp & $=$ & ++ & \\
\hline & Min soil temp & $=$ & -- & \\
\hline & Wind & + & +++ & \\
\hline & Solar radiation & + & +++ & \\
\hline \multirow[t]{5}{*}{ Soil } & Moisture & $=$ & +++ & Martínez Pastur et al. 2013b, 2014; Soler et al. 2015 \\
\hline & Compaction & $=$ & ++ & \\
\hline & Carbon & $=$ & - & \\
\hline & Nitrogen & $=$ & - & \\
\hline & Phosphorous & $=$ & + & \\
\hline
\end{tabular}

are greatly increased in the harvested areas (23.8 \pm $3.9 \mathrm{~W} \mathrm{~m}^{2}$ and $27.6 \pm 4.1 \mathrm{~W} \mathrm{~m}^{2}$ with and without the influence of aggregates patches in the dispersed retention). These changes in microclimate were also documented for the implementation of variable retention around the world (Bladon et al. 2006; Heithecker and Halpern 2007).

Most of the soil properties slightly changed due to harvesting (Martínez Pastur et al. 2013b, 2014; Hewitt et al. 2018) (Table 2): (i) pH slightly increased (5.9 \pm 0.2 in aggregate patches and $6.1 \pm 0.1$ in the dispersed retention), (ii) cation exchange capacity slightly decreased (16.5 \pm $0.3 \mathrm{meq} 100 \mathrm{~g}$ in aggregate patches and $15.7 \pm 0.9 \mathrm{meq}$ $100 \mathrm{~g}$ in the dispersed retention), (iii) soil carbon and nitrogen decreased $(14.9 \pm 4.8 \%$ and $0.5 \pm 0.3 \%$ in aggregate patches, and $10.9 \pm 2.1 \%$ and $0.4 \pm 0.2 \%$ in the dispersed retention, respectively), and the available phosphorous increased due to microbial activity $(115.0 \pm 9.7 \mathrm{ppm}$ in aggregate patches and $126.8 \pm 12.0 \mathrm{ppm}$ in the dispersed retention). However, soil compaction increased in the harvested areas due to skidders (Martínez Pastur et al. 2014). In our plots, we measured soil compaction 10 years after harvesting, where primary unmanaged forests presented the less compacted soils $\left(238 \pm 95 \mathrm{~N} \mathrm{~cm}^{-2}\right)$ and gradually increased in the harvested stands $\left(268 \pm 100 \mathrm{~N} \mathrm{~cm}^{-2}\right.$ in aggregate patches, $292 \pm 84 \mathrm{~N} \mathrm{~cm}^{-2}$ in the dispersed retention under the influence of the aggregate patches, and $328 \pm 98 \mathrm{~N} \mathrm{~cm}^{-2}$ outside the influence of the aggregate patches). Furthermore, decomposition and nutrient cycles are greatly influenced by harvesting, mainly due to these changes in microclimate and soil conditions (Caldentey et al. 2001). Primary unmanaged forests and aggregate patches presented similar decomposition rates and lower to those found in the dispersed retention. In fact, the dispersed retention also presents the lowest $\mathrm{C} / \mathrm{N}$ ratio, and releases more phosphorus (Oro Castro et al. 2018). Variable retention generated great variability in micro- 
environmental conditions that offer different microclimate and soil characteristics along the different forest structure gradients, e.g., from closed canopies in aggregate patches to open environments in the dispersed retention without the influence of aggregates patches. Finally, debris accumulation in the harvested area was not homogeneous, which also generated diverse microenvironments (e.g., shelter to avoid sunlight over-exposure or protection against browsing) (Martínez Pastur et al. 2011b, 2014).

\section{Natural regeneration dynamics}

Regeneration dynamic is greatly influenced by the microenvironments in the forest floor (soil moisture and light availability), and quickly reacted to changes due to harvesting (Martínez Pastur et al. 2011b, 2014). For example, (i) closeness to live trees decreased soil moisture $(42-46 \%$ of the area in primary unmanaged forests and aggregate patches, and $8-10 \%$ in the dispersed retention), (ii) skidders paths compacted the soil but increased the water availability (19$24 \%$ of the area in the dispersed retention), and (iii) woody debris generated positive (e.g., shelter) and negative (e.g., excessive shadow) effects (53-58\% of the area in primary unmanaged forests and aggregate patches, and increased to $63-67 \%$ in the dispersed retention). These influences included several positive and negative effects that greatly affected the eco-physiological performance of seedlings and saplings (Martínez Pastur et al. 2007b, 2014; Peri et al. 2009; Soler et al. 2011; Ivancich et al. 2012).

The flowering and seeding cycles in N. pumilio forests are influenced by different yearly flower (male and female) production, which potentially derived in fruits and seeds (Martínez Pastur et al. 2008, 2013a) (Table 2). These seeds reached to the forest floor during early autumn before leaves fall down. During this cycle, flowers, fruits, and seeds are foraged by birds, mice, and insects. One of the main bottleneck was the shelter of seeds during winter, since they are stratified under litter and snow to germinate during late spring. This species has a seedling bank, which greatly varied along the years because masting seed production varied along the years (Martínez Pastur et al. 2008, 2013a). These events were also observed in several broadleaved temperate forests around the world (Wagner et al. 2010; Dey et al. 2019). Harvesting also influenced these cycles, and variable retention generated gradients across the managed stands. In our long-term permanent plots (Ea. Los Cerros) (Fig. 1), primary unmanaged forests presented the greatest seed production $\left(9.7 \pm 8.8\right.$ mill ha ${ }^{-1}$, maximum 33.4 mill ha $\left.^{-1}\right)$ followed by the aggregate patches $\left(7.6 \pm 4.3 \mathrm{mill} \mathrm{ha}^{-1}\right.$, maximum $\left.14.2 \mathrm{mill} \mathrm{ha}^{-1}\right)$ and the dispersed retention $(2.4 \pm 1.5$ mill ha ${ }^{-1}$ and $1.2 \pm 0.7$ mill ha $^{-1}$ with or without the influence of aggregate patches, maximum 10.5-20.0 mill ha ${ }^{-1}$ ). Harvesting also influenced litter production. Litter production in primary unmanaged forests $\left(3.4 \pm 0.9\right.$ ton $\left.\mathrm{ha}^{-1}\right)$ decreased along the canopy cover gradient in the harvested stands: aggregate patches $\left(3.0 \pm 0.8\right.$ ton $\left.\mathrm{ha}^{-1}\right)$ was greater than the dispersed retention $\left(1.2 \pm 0.5\right.$ ton $\mathrm{ha}^{-1}$ and $0.6 \pm$ 0.2 ton $\mathrm{ha}^{-1}$ with and without the influence of aggregate patches). In this sense, harvesting generated a double limitation for new regeneration recruitment: reduction in seed availability and litter production to protect the seeds during winter. Aggregate patches ameliorated this limitation by increasing the regeneration according to the microclimate conditions in their influencing areas (Martínez Pastur et al. 2011b).

Regeneration dynamics presented great differences between primary unmanaged forests and retention types in harvested areas (Table 2, Fig. 3). Regeneration in primary unmanaged forests greatly varied among the years from 11.1 to 1061.7 thousand $\mathrm{ha}^{-1}$, with plants less than 13 years old and $5.5 \mathrm{~cm}$ height (average growth of $0.4 \mathrm{~cm}$ year $^{-1}$ ). Within aggregate patches, similar recruitment pattern was found, but regeneration survived for longer periods of time after harvesting (60.6 to 1056.7 thousand $\mathrm{ha}^{-1}$ with plants that reached to 16 years old and $32.1 \mathrm{~cm}$ height, average growth of $2.0 \mathrm{~cm} \mathrm{year}^{-1}$ ). In the dispersed retention, many plants of the seedling bank survived after harvesting (e.g., damages due to mechanical damages, frost, or dryness), but decreased along the years ( 47.2 to 8.6 thousand $\mathrm{ha}^{-1}$ and 37.8 to 20.9 thousand $\mathrm{ha}^{-1}$ with or without the influence of aggregate patches). This natural regeneration was complemented with new plants that mostly are recruited 45 years after harvesting, with variations due to recruitment and mortality events (86.7 to 30.4 thousand $\mathrm{ha}^{-1}$ and 60.6 to 42.7 thousand $\mathrm{ha}^{-1}$ with or without the influence of aggregate patches). During this time, the regeneration reached to more than $90 \mathrm{~cm}$ height in the dispersed retention (average growth $4.6 \mathrm{~cm}$ year $^{-1}$ ). This natural regeneration was enough to regenerate the harvested areas according to the proposed silvicultural management (Martínez Pastur et al. 2011a, b).

\section{Understory plants}

Understory plants are the most used indicators of sustainability in the temperate $N$. pumilio forests, due to their importance in ecosystem function (Lencinas et al. 2011). The assemblage of the understory species in this Southern Patagonian forests is simple (20 to 40 species of vascular plants), and the vegetation cover is scarce (< 40\%) (Lencinas et al. 2008a, 2017), but was similar compared to other temperate forests (Decocq et al. 2004; Frelich et al. 2015). Harvesting significantly affected the understory plant diversity and cover, and the magnitude of this change depended on their intensity (Table 1). One of the studies conducted in Tierra del Fuego (San Justo Ranch) (Fig. 1) defined a baseline along a site quality gradient before the harvesting (Lencinas et al. 2011). They found 31 plant species, where richness, cover, and 


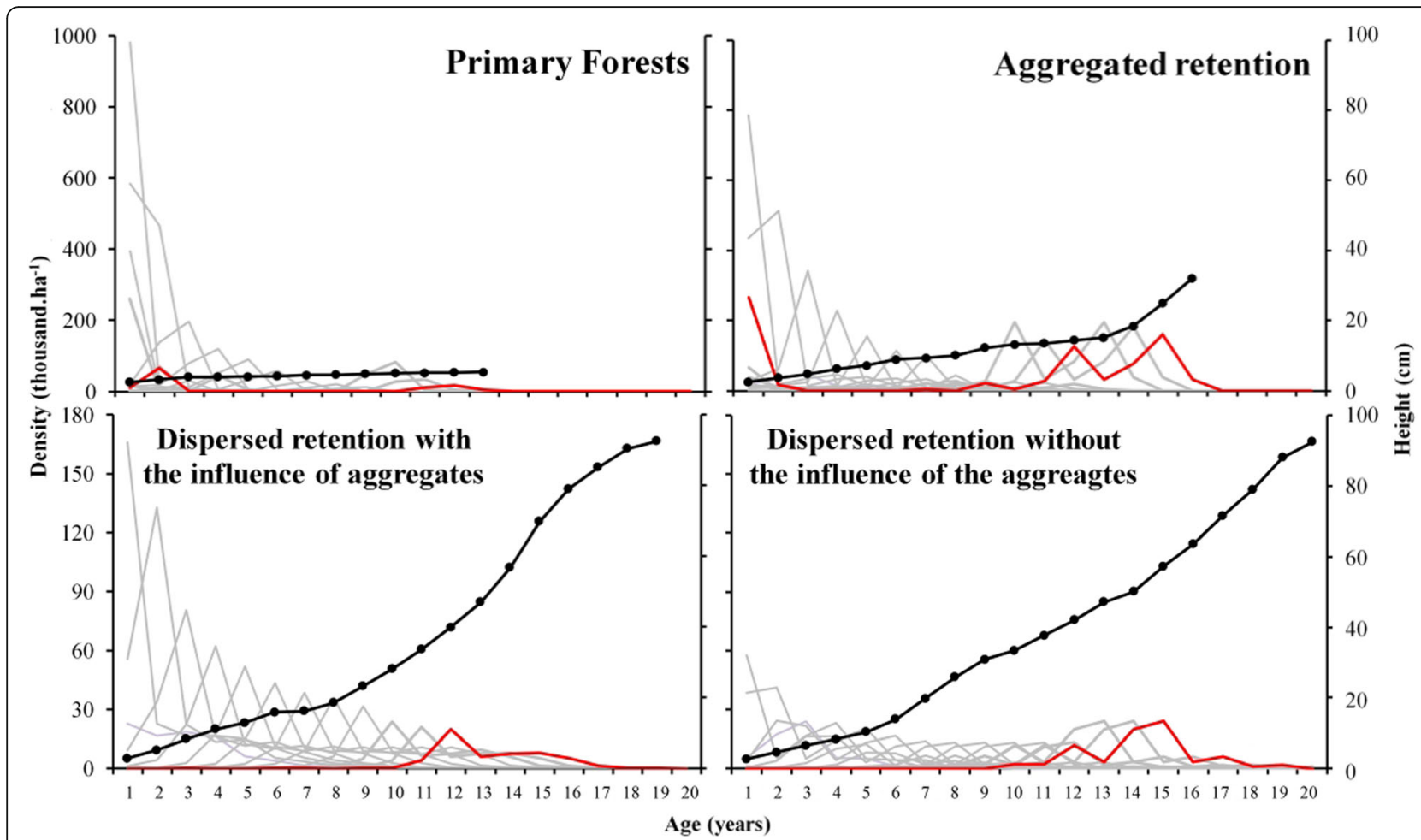

Fig. 3 Regeneration structure (age and density) and height growth in primary unmanaged forests and variable retention harvesting (aggregate patches and dispersed retention). In red, the regeneration structure 15 years after harvesting, and in gray, the previous years. The plots corresponded to PEBANPA network at Los Cerros Ranch (Tierra del Fuego) (see Peri et al. 2016)

biomass increased with site quality, as well as Gallo et al. (2013) described for shelterwood cuts. Several species only occurred in the N. pumilio forest understory (e.g., some orchids and ferns) or canopy (e.g., some mistletoe species), and were not represented in the landscape (Lencinas et al. 2008a). After variable retention harvesting, 20 new species appeared from adjacent associated environments (two from Nothofagus antarctica forests and 18 from grasslands and peatlands). The impact was greater in the dispersed retention than in aggregate patches, which presented more similarities with primary unmanaged forests (81-95\% of plant richness at baseline conditions was conserved in the harvested areas with variable retention). Dicots and monocots increased after harvesting in aggregate patches, but greatly increased in the dispersed retention. Exotic species also increased in the harvested areas, including the colonization of the aggregate patches (Lencinas et al. 2011, 2017; Soler et al. 2015, 2016). Mistletoe species was another group that also increased in the harvested areas, generating a large damage in remnant trees of aggregate patches and dispersed retention (Soler et al. 2014). A combination of aggregate patches and dispersed retention was the better choice to limit the exotic species introduction (e.g., Taraxacum officinale and Cerastium fontanum are indicator species of disturbance in the dispersed retention) (Lencinas et al.
2017) and to protect sensitive species (e.g., Viola magellanica or Dysopsis glechomoides) (Lencinas et al. 2011), improving conservation in harvested stands (Fig. 4). The main changes in the understory variables are observed during the first 3 years after harvesting, and then the values are stabilized. Plant invasion decreased over time and native plant species recovered the understory before the massive regeneration occur (Soler et al. 2016; Lencinas et al. 2017). Aggregate patches improved the survival of several native plants, and facilitated the re-colonization of some species in the harvested areas. The regeneration of the harvested areas generated secondary forests with close canopies after 20-30 years, and drastically reduced the richness and cover of the understory. However, the mature stands will include some exotic species that entry to the system after the harvesting, and that will not disappear on time (Martínez Pastur et al. 2002; Soler et al. 2016). For this, in the case of the plant understory, variable retention mitigates the harmful effects of traditional practices on biodiversity of forest ecosystems, preserving the habitats for species affiliated with closed forests and providing habitats for early-seral species.

\section{Bird communities}

The study at San Justo Ranch in Tierra del Fuego (Fig. 1) defined a baseline for birds along a site quality gradient 


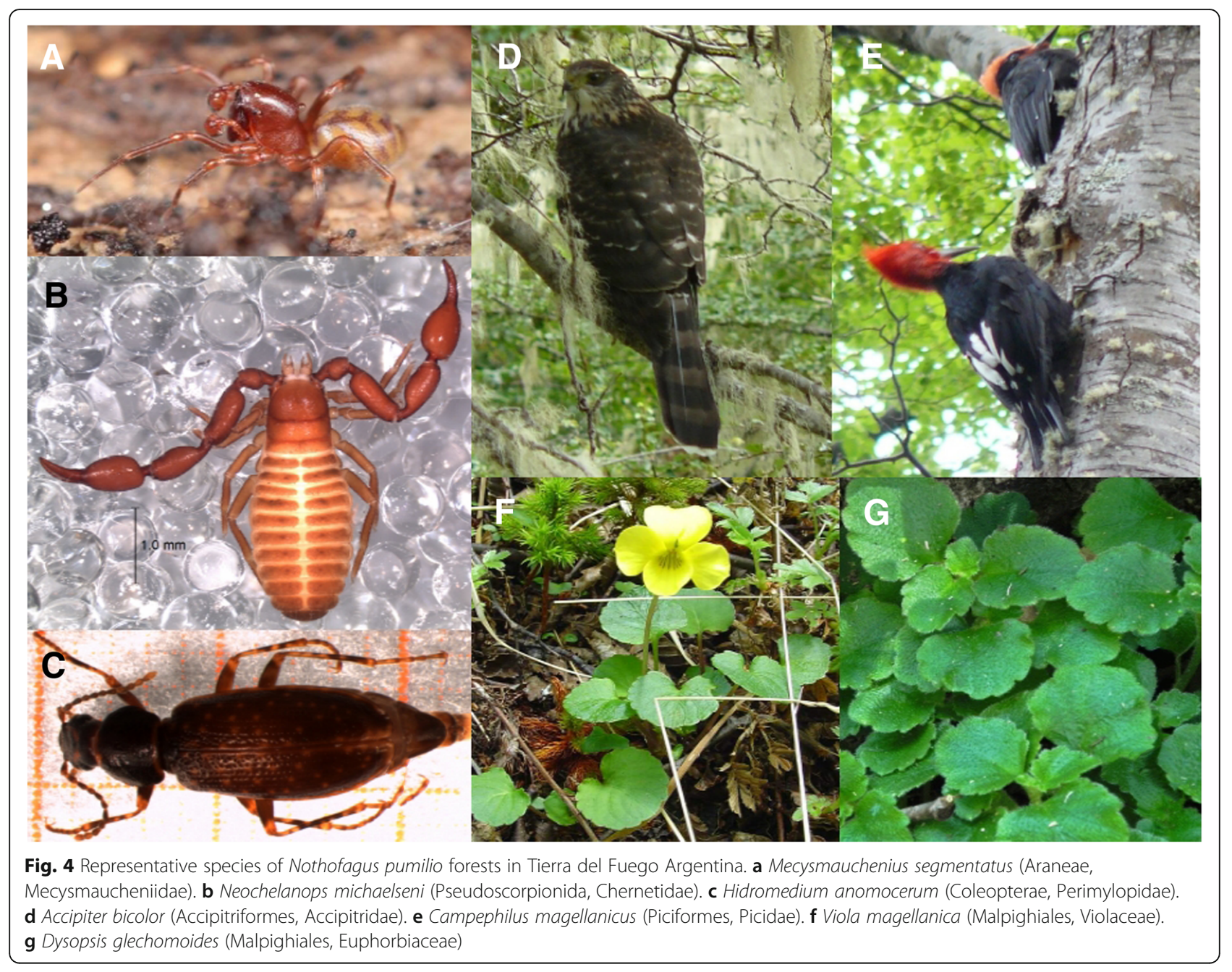

before and after harvesting (Lencinas et al. 2009) and quantified the changes of the habitat use (Lencinas et al. 2018). Birds at this latitude are generalist and usually migrants; however, some species are specialist that preferred primary unmanaged forests (e.g., Campephilus magellanicus or Accipiter bicolor) (Lencinas et al. 2005, 2009, 2018; Vergara and Schlatter 2006) (Table 1$)$. Bird species richness and density (15 species and 9.2 ind ha ${ }^{-1}$ ) did not changed with site quality and canopy gap presence in primary unmanaged forests. However, both variables were modified in harvested stands, increased over time up to 18 species and 39 ind $\mathrm{ha}^{-1}$ (Lencinas et al. 2009). Inside aggregate patches, bird communities were similar to primary unmanaged forests compared with the dispersed retention. Species presented differential habitat preference after harvesting (Vergara and Schlatter 2006; Lencinas et al. 2018). Thus, while some species (Carduelis barbata, Phrygilus patagonicus, and Tachycineta leucopyga) preferred harvested forests with more retention (e.g., aggregate patches and dispersed retention), others (Enicognathus ferrugineus, Troglodytes aedon, and Zonotrichia capensis) preferred more open harvested environments (a combination of aggregate patches and clearcuts) (Lencinas et al. 2018). Harvesting based on variable retention maintained enough vegetation structure in the managed stand to permit the establishment of early successional birds (at least in the dispersed retention), and to maintain the bird species of primary unmanaged forests which could persist in the aggregate patches (Vergara and Schlatter 2006; Lencinas et al. 2009, 2018).

\section{Arthropods}

This group conforms the phylum Euarthropoda, and includes several taxa (e.g., insects and arachnids). Usually, these small animals were left outside of conservation programs and ecosystem management planning (New 2018). However, this group represents the greatest richness in many ecosystems, especially those located at higher latitudes (Lencinas et al. 2012). Bio-indicators could act as early warning proxy of environmental changes, ecosystem 
stress, or taxonomic diversity, and arthropods are among the most sensible to changes due to natural or human impacts (Lencinas et al. 2008b). Among them, insects are identified as the most threatened group to the forest harvesting in $N$. pumilio forests, with a local extinction rate of one species every 11 years along the forest management cycle (Spagarino et al. 2001). For this, variable retention harvesting was proposed to enhance the conservation of arthropod communities in managed areas, mitigating the species losses of the original forest communities. The study at San Justo Ranch in Tierra del Fuego (Fig. 1) also defined a baseline for several insect orders along a site quality gradient before and after harvesting (Lencinas et al. 2010, 2012, 2014). There were 79 mobile epigean species in the primary unmanaged forests before harvesting despite the site quality. After harvesting, 84 new species were added in the harvested areas and the species of primary unmanaged forests diminished according to the retention degree. The most sensitive orders according to Lencinas et al. (2015) were (between brackets, it was presented the species richness in primary forests, aggregate patches, and dispersed retention): Coleoptera $(24,22,15)>$ Hymenoptera $(33,32,22)>$ Diptera $(47,43,40)>$ Lepidoptera $(20,21,18)$, followed by the less represented orders: Homoptera $(3,4,2)$, Psocoptera (2, 2 , 2), Hemiptera $(1,1,2)$, Ephemeroptera $(1,0,0)$, Trichoptera $(1,0,0)$, Neuroptera $(1,0,1)$, and Plecoptera $(1,0,1)$. In this sense, harvesting reduced insect richness in $N$. pumilio forests independently of the harvesting or retention type. The original insect assemblage changed due to loss of sensitive species and the introduction of other species from the surrounding environments. Despite this, the inclusion of aggregate patches greatly diminishes the harvesting impact in the managed areas, because insect assemblage has been favored with the preservation of the structural complexity, conserving richness, and abundance at similar levels to those in primary unmanaged forests (Lencinas et al. 2010, 2012, 2014). The specialist vs. generalist species in the original assemblage could influence the resistance/resilience of the community, since primary unmanaged forests assemblages with a greater proportion of generalist and/or non-sensitive species could be maintained in aggregate patches. The influx of species (mainly generalists or exploiters) occurred mainly in the dispersed retention, generating higher dissimilarities with primary unmanaged forests (Lencinas et al. 2017). Finally, the utility of potential bio-indicators could differ for a particular locality. Particularities in the biotic assemblages in a regional gradient are important for management and conservation planning, and variable retention becomes a useful strategy that combines conservation and production objectives in a managed landscape. For this, insects can act a potential bio-indicators (e.g., Hidromedium anomocerum) (Fig. 4), but it is necessary to identify them in baseline before harvesting in long-term monitoring programs (Lencinas et al. 2014, 2017).

Another study characterized the benthic macro-invertebrate community structure and function in streams, comparing the impact of harvesting type and beavers (Castor canadensis) (Simanonok et al. 2011). Environmental variables did not greatly changed, except for dissolved oxygen that was significantly higher in streams of primary unmanaged forests. Benthic communities in beaver meadows had significantly lower diversity compared with streams in primary unmanaged forests, with intermediate values in the harvested areas. Benthic community in beaver meadows displayed a reduction of all functional feeding groups except collector-gatherers. Variable retention harvesting with riparian buffers was similar to primary unmanaged forest streams, while shelterwood cuts occupied an intermediate position. These results indicated that forestry practices that include both variable retention types (aggregate patches and dispersed retention) with protected riparianforested buffers might be effective in mitigating impacts on stream benthic communities.

Arachnids are also an important group because they are top predators. Among them, spiders and pseudoscorpions are key elements in the micro-fauna of the N. pumilio forests (Fig. 4). However, they have rarely been used as bio-indicators because of the lack of information about their ecology, habitat selection, niche preferences, and specific requirements. Spiders also showed similar pattern to insects, where original assemblage species of primary unmanaged forests (18 species) partially survive in the harvested areas (72\% of the species), both in aggregate patches (ten species) and in the dispersed retention (11 species). Besides this, several new species arrive from surrounding open-environments (eight species). In this sense, a combination of both retention types was effective to maintain spider biodiversity, but it is not enough to protect and conserve all the assemblage in the managed areas. Pseudoscorpions were found all around the landscape, but they preferred the forested areas, e.g., Neochelanops michaelseni abundance was higher in forests than in open ecosystems, which could be attributed to their affinity for litter and coarse woody debris (Fig. 4). For this, it can be used as a potential bio-indicator, decreasing in their abundance with the impact degree in the harvested areas compared to primary unmanaged forests (Lencinas et al. 2015).

\section{Other groups}

There are several studies that investigate other groups in these forests including large mammals (e.g., Lama guanicoe), understory mosses, epiphytic lichens, mistletoes, and fungi communities of phylloplane or mycorrhizae in the natural regeneration (Table 1) (Ducid et al. 2005; Lencinas et al. 2008c; Soler et al. 2012, 2014; Martínez 
Pastur et al. 2016b; Hewitt et al. 2018). Lama guanicoe was identified as one of the major threats for natural regeneration, due to browsing that occurred in primary unmanaged and managed forests. Browsing happens all year round (Soler et al. 2012) and negative effects with livestock (cattle and sheep) were identified. This suggests the potential over-uses of some environments due to niche segregation, e.g., livestock usually feed in open-lands and L. guanicoe must move to forested environments (Martínez Pastur et al. 2016b). Browsing was greater when tree plants were higher than understory (> $0.3 \mathrm{~m}$ ) and when regeneration presented a dispersed distribution pattern. Variable retention did not impede the browsing, and the abundant understory grass and herb attracted L. guanicoe and livestock. For example, at long-term plot of Los Cerros Ranch (Fig. 1), we found $0.1 \%$ of browsing in primary unmanaged forests $(0.0 \%$ to $1.1 \%)$ that increased in aggregate patches to $5.83 \%(0.0 \%$ to $19.6 \%$ ) due to L. guanicoe and livestock uses them for shelter during night. In the harvested areas, the browsing greatly increased (11.2\%), presenting variations among the years $(0.0 \%$ to $35.6 \%)$. These variations were related to climatic change (e.g., ENSO) that influenced the length of the growing season (Torres et al. 2015). Despite the browsing effect on early regeneration, it was found that the browsing did not limit the regeneration of the stands, where the use of fences or hunting did not improve the long-term development of the regeneration (Martínez Pastur et al. 2016b).

Bryophyte communities are another essential component of the understory in N. pumilio forests, and usually it was not employed as bio-indicators due to the lack of knowledge for their taxonomy identification. Bryophytes were also significantly affected by harvesting. The same study at San Justo Ranch in Tierra del Fuego (Fig. 1) defined a baseline for bryophyte communities along a site quality gradient, as well as before and after the harvesting (Lencinas et al. 2008c). The baseline determined that bryophyte communities were more abundant in low (13\% cover and $844 \mathrm{~kg} \mathrm{ha}^{-1}$ biomass) than in high site quality classes ( $5 \%$ cover and $357 \mathrm{~kg} \mathrm{ha}^{-1}$ ), while biomass differences were found inside the canopy gaps $\left(1404 \mathrm{~kg} \mathrm{ha}^{-1}\right)$. This indicates that primary unmanaged forests have different conservation values for bryophytes, and this must be considered when conservation strategies are proposed (e.g., include different site quality stands). After harvesting, most of the primary unmanaged forests species decreased in the harvested sectors with dispersed retention, but the original communities survived inside the aggregate patches. However, some life forms as tall turf and lax weft grow better in harvested areas. For this, variable retention appears as the most adequate strategy to maintain the bryophyte biodiversity in the managed stands.
Furthermore, harvesting affected epiphytic lichens (Usnea barbata) and mistletoes (Misodendrum punctulatum). Canopy cover influenced tree, mistletoe, and lichen biomasses, being higher in primary unmanaged forests than in harvested stands where lichen biomass decreased over the years after harvesting. However, aggregate patches showed the highest mistletoe biomass production. Furthermore, mistletoe biomass increased while lichen biomass decreased over the years after harvesting. By the contrary, aggregate patches were not enough to maintain the original level of lichen populations. Forest harvesting with variable retention generated positive (litter input) and negative (decline of host growth) effects on epiphytic lichens at community level, which should be evaluated during conservation and management planning (Soler et al. 2014).

Fungi communities are the less studied group, and probably represent the largest percentage of the total biodiversity in N. pumilio forests. However, few studies analyze the impact of harvesting on these communities. One study analyzed the fungi communities of phylloplane in one characteristic species of the understory (Osmorhiza chilensis) in San Justo long-term plot (Ducid et al. 2005) (Fig. 1). The species richness and abundance were directly related with the canopy retention, where major losses were found in the most intensive harvested areas. These changes in the canopy also favored the introduction of new species from surrounding environments that modified the original species assemblage. A second study defined that timber harvesting also modified the abundance and composition of ectomycorrhizal community structure (most of them are Basidiomycota belonging to the families Cortinariaceae, Inocybaceae, and Thelephoraceae), but the impacts of harvesting varied with the management strategy (Hewitt et al. 2018). Ectomycorrhizal fungi richness and colonization were reduced in the dispersed retention compared to aggregate patches and primary unmanaged forests. This suggests that variable retention has the potential to improve the conservation status of managed stands by supporting native ectomycorrhizal fungi in aggregate patches. This study highlights the complex linkages between retention treatments, fungal community composition, and tree growth at individual and stand scales, as were reported for several management alternatives around the world (Lewandowski et al. 2019).

\section{Positive and negative effects of the variable retention: where do we go from here?}

Soler et al. $(2015,2016)$ synthetized hundreds of individual results from long-term studies in variable retention harvesting in Tierra del Fuego (Argentina) using meta-analyses techniques, including (i) forest structure, (ii) microenvironment, (iii) biodiversity, and (iv) forest reproduction. In 
general, they found that aggregate patches did not present significant changes in the meta-analyses on forest structure and micro-environmental variables, but increased biodiversity variables and forest reproduction compared to primary unmanaged forests. The meta-analyses also showed that dispersed retention negatively affected the forest structure, increased biodiversity, but did not significantly affect microclimate and forest reproduction as compared to primary unmanaged forests. The direction and magnitude of the effect depend on the treatment and differ among groups of retention types (Soler et al. 2015). Biodiversity can be analyzed from different perspectives, e.g., from the overall richness or considering the original biodiversity that was supported by primary unmanaged forests. In this sense, forests managed with variable retention harvesting supported higher overall richness and abundance of plants, insects, and birds in aggregate patches and dispersed retention than primary unmanaged forests. However, aggregate patches supported higher native forest specialist plants and lower plants species than the dispersed retention. Both retention treatments increased exotic plants, although its richness and abundance was higher in the dispersed retention. Specialist insects from native forest were reduced in comparison to primary unmanaged forests, while insects of other habitats showed a positive response to both aggregate patches and dispersed retention. Similar trend was found for bird species richness and abundance compared to primary unmanaged forests. These meta-analyses studies showed a recovery toward original conditions for some taxa, but demonstrated a long-term establishment of exotic plants as well as insect species not associated with native $N$. pumilio forests. In few words, variable retention could play a fundamental role for conservation in these forests, but the influence of retention pattern and aggregate patch size are still unclear. More studies are necessary to evaluate the effects of different aggregate patch size, shape, and distribution into harvested forests, as well as their fragmentation and connectivity at landscape level.

In Tierra del Fuego, the implementation of this method is well supported in terms of timber yield and economic advantages by the local industries. However, the variable retention harvesting design must be updated to better conserve some taxa groups that are not fully protected in the medium and long-term. To develop these new alternatives, it is necessary to have more studies about the auto-ecology and ecological function of the species. Besides this, there are a great variability in the assemblages at landscape level (Lencinas et al. 2017; Huertas Herrera et al. 2018), and the implementation of the variable retention harvesting must be monitored along a wide environmental gradients.

Variable retention harvesting concept can be applied in a wide spectrum of management proposals (e.g., for shrubs management, Sola et al. 2016) and considering different objectives (e.g., from provision of several ecosystem services to biodiversity conservation) (Luque et al. 2010; Martínez Pastur et al. 2013b; Perera et al. 2018; Lindenmayer et al. 2019). This method became a useful tool to conserve biodiversity and ecosystem functions, reaching the balance between economy, ecology, and social requirements in the managed areas. For this, the most important challenge for Southern Patagonia is to (i) include the concept in the forest policy agenda, and (ii) improve the proposal at different landscape levels (e.g., from regional to stand levels). Besides this, the long-term research allowed us to define actionable recommendations for best management practices using variable retention harvesting to practitioners: (i) characterize the landscape to identify areas with high conservation values within the protected areas due to local regulations, and complement these areas with reserves of timber forests at medium-scale; (ii) reduce the impact on riparian forests and remove Castor canadensis burrows; (iii) maintain the integrity of aggregate patches, reducing the soil impacts and damages on dispersed retention trees during harvesting operations; (iv) create additional aggregate patches if nests or burrows on trees of rare species were found (e.g. foxes, bats); (v) avoid the woody debris accumulation, preferring an homogeneous distribution across the dispersed retention; (vi) monitor invasive species through reliable indicators in order to avoid undesirable changes of the original communities that impede the natural regeneration or greatly influenced over the natural cycles; (vii) monitor regeneration dynamics and the potential trade-offs with native (e.g., Lama guanicoe browsing) or introduced herbivores (e.g., cattle); and (viii) monitor the natural cycles and biodiversity in order to modify the implemented proposal of variable retention harvesting during the next management cycle (adaptive environmental assessment and management), which can be useful also considering the climate change in the long term.

\section{Conclusions}

Variable retention harvesting was successfully implemented in Tierra del Fuego (Argentina) since 2001, mainly by the ownerships of sawmills and ranches. The proposal presented yields comparable to traditional harvesting, and decreased the costs of cutting and skidding operations. Long-term plots quantify the conservation values and the changes in the natural cycles and ecosystem services provision in the managed stands. Variable retention harvesting generates biotic and abiotic gradients in the managed stands, e.g., from closed canopies inside the aggregate patches to large openings in the dispersed retention outside the influence of the aggregate patches. These gradients allowed the maintenance of the biodiversity of the primary unmanaged forests inside the 
aggregate patches but offered adequate conditions for other species (e.g., exotic and other native species that live in the surrounding ecosystems). The natural cycles also followed the same pattern, maintaining similar trends of the primary unmanaged forests inside the aggregate patches but greatly changed in the dispersed retention. Variable retention proposal combines the economic and ecological values, reaching to an equilibrium of both objectives in the forest management and conservation planning. Medium- to long-term (20 to 100 years) research is still needed to test the outputs along the full management cycle. Finally, other alternatives must be tested (e.g., different aggregate patch sizes) and these new proposals must be designed for those species that present local extinction, being necessary more studies about the auto-ecology and habitat requirements.

\section{Acknowledgements}

To the researchers, technicians, students, and ownerships (ranch and sawmill companies) that support this research in the long-term. It was impossible to obtain these invaluable data without their disinterested and unconditional help.

\section{Funding}

Different projects from national and international calls between 1997 to date.

\section{Availability of data and materials}

At CADIC repository.

\section{Authors' contributions}

All the authors collaborate in equal participation to write the manuscript. All authors read and approved the final manuscript.

\section{Ethics approval and consent to participate}

No ethics or conflict of interest exists.

\section{Consent for publication}

Not applicable.

\section{Competing interests}

The authors declare that they have no competing interests.

\section{Publisher's Note}

Springer Nature remains neutral with regard to jurisdictional claims in published maps and institutional affiliations.

\footnotetext{
Author details

${ }^{1}$ Centro Austral de Investigaciones Científicas (CADIC), Consejo Nacional de Investigaciones Científicas y Técnicas (CONICET), Houssay 200 (9410), Ushuaia, Tierra del Fuego, Argentina. ${ }^{2}$ Universidad Nacional de la Plata (UNLP), Calle 7 e/ 47 y 48 (1900) La Plata, Buenos Aires, Argentina. Instituto Nacional de Tecnología Agropecuaria (INTA), Universidad Nacional de la Patagonia Austral (UNPA), Consejo Nacional de Investigaciones Científicas y Técnicas (CONICET), cc 332 (9400), Río Gallegos, Santa Cruz, Argentina.
}

Received: 20 March 2019 Accepted: 14 May 2019

Published online: 01 July 2019

\section{References}

Bladon KD, Landhäusser SM, Lieffers VJ (2006) Differential transpiration by three boreal tree species in response to increased evaporative demand after variable retention harvesting. Agric For Meteor 138:104-119

Caldentey J, Ibarra M, Hernández J (2001) Litter fluxes and decomposition in Nothofagus pumilio stands in the region of Magallanes, Chile. For Ecol Manag 148:145-157
Caldentey J, Ibarra M, Promis A (2005) Microclimatic variations in a Nothofagus pumilio forest caused by shelterwood systems: results of seven years ofobservations. Int For Rev 7(5):46

Caldentey J, Mayer H, Ibarra M, Promis A (2009) The effects of a regeneration felling on photosynthetic photon flux density and regeneration growth in a Nothofagus pumilio forest. Eur J For Res 128:75-84

Cellini JM, Martínez Pastur G, Soler R, Barrera MD, Lencinas MV (2013) Retención variable en bosques de Nothofagus pumilio (Poepp. et Endl.) Krasser en Patagonia Sur: Estructura forestal, estabilidad estructural y regeneración. Yvyraretá 20:40-47

Decocq G, Aubert M, Dupont F, Alard D, Saguez R, Wattez-Franger A, De Foucault B, Delelis-Dusollier A, Bardat J (2004) Plant diversity in a managed temperate deciduous forest: understorey response to two silvicultural. systems. J Appl Ecol 41(6):1065-1079

Deferrari G, Camilión C, Martínez Pastur G, Peri PL (2001) Changes in Nothofagus pumilio forest biodiversity during the forest management cycle: birds. Biodivers Conserv 10(12):2093-2108

Dey DC, Knapp BO, Battaglia MA, Deal RL, Hart JL, O'Hara K, Schweitzer C, Schuler TM (2019) Barriers to natural regeneration in temperate forests across the USA. New For 50(1):11-40

Donoso PJ, Schlegel BC, Salas-Eljatib C, Donoso C (2019) Development of 26-yearold mixed forests following different regeneration cutting treatments in Andean temperate rainforests of south-central Chile. For Ecol Manag 432:686-693

Ducid MG, Murace MA, Cellini JM (2005) Diversidad fúngica en el filoplano de Osmorhiza spp. relacionado con el sistema de regeneración empleado en bosques de Nothofagus pumilio en Tierra del Fuego, Argentina. Bosque 26(1):33-42

Frangi JL, Richter L (1994) Balances hídricos de bosques de Nothofagus de Tierra del Fuego. Argentina Rev Fac Agron La Plata 70:65-79

Franklin JF, Berg DE, Thornburgh DA, Tappeiner JC (1997) Alternative silvicultural approaches to timber harvest: variable retention harvest systems. In: Kohm KA, Franklin JF (eds) Creating a forestry for the $21^{\text {st }}$ century. Island Press, Covelo, pp 111-139

Franklin JF, Forman RT (1987) Creating landscape patterns by forest cutting: ecological consequences and principles. Landsc Ecol 1:5-18

Frelich LE, Montgomery RA, Oleksyn J (2015) Northern temperate forests. In: Peh $\mathrm{K}$, Corlett RT, Bergeron Y (eds) Routledge handbook of forest ecology. Taylor and Francis, London, pp 30-45

Gallo E, Lencinas MV, Martínez Pastur G (2013) Site quality influence over understory plant diversity in old-growth and harvested stands of Nothofagus pumilio forest. For Syst 22(1):25-38

Gamondés Moyano I, Morgan RK, Martínez Pastur G (2016) Reshaping forest management in southern Patagonia: a qualitative assessment. Sust For 35(1):37-59

Gea G, Martínez Pastur G, Cellini JM, Lencinas MV (2004) Forty years of silvicultural management in southern Nothofagus pumilio (Poepp. et Endl.) Krasser primary forests. For Ecol Manag 201(2-3):335-347

Gustafsson L, Baker S, Bauhus J, Beese W, Brodie A, Kouki J, Lindenmayer D, Löhmus A, Martínez Pastur G, Messier C, Neyland M, Palik B, Sverdrup-Thygeson A, Volney J, Wayne A, Franklin J (2012) Retention forestry to maintain multifunctional forests: a world perspective. Bioscience 62(7):633-645

Hankin LE, Higuera PE, Davis KT, Dobrowski SZ (2019) Impacts of growing-season climate on tree growth and post-fire regeneration in ponderosa pine and Douglas-fir forests. Ecosphere 10(4):e2679

Heithecker TD, Halpern CB (2007) Edge-related gradients in microclimate in forest aggregates following structural retention harvests in western Washington. For Ecol Manag 248:163-173

Hewitt R, Taylor L, Hollingsworth T, Anderson CB, Martínez Pastur G (2018) Variable retention harvesting influences belowground plant-fungal interactions of Nothofagus pumilio seedlings in forests of southern Patagonia. PeerJ 6:e5008

Huertas Herrera A, Cellini JM, Barrera MD, Lencinas MV, Martínez Pastur G (2018) Environmental gradients and anthropogenic impacts as main drivers for the invasion of exotics plants in forest mountain landscapes of South Patagonia. For Ecol Manag 430:380-393

Ivancich H, Lencinas MV, Martínez Pastur G, Soler R, Hernández L, Lindstrom I (2012) Foliar anatomical and morphological variation in Nothofagus pumilio seedlings under controlled irradiance and soil moisture levels. Tree Physiol 32(5):554-564

Kozlowski T (2002) Physiological ecology of natural regeneration of harvested and disturbed forest stands: implications for forest management. For Ecol Manag 158:195-221 
Lencinas MV, Cellini JM, Benitez J, Peri PL, Martínez Pastur G (2018) Variable retention forestry conserves habitat of bird species in Patagonian Nothofagus pumilio forests. Ann For Res 61(2):147-160

Lencinas MV, Kreps G, Soler R, Peri PL, Porta A, Ramírez M, Martínez Pastur G (2015) Neochelanops michaelseni (Pseudoscorpions: Chernetidae) as potential bioindicator in managed and unmanaged Nothofagus forests of Tierra del Fuego. J Arach 43:406-412

Lencinas MV, Martínez Pastur G, Anderson C, Busso C (2008b) The value of timber quality forests for insect conservation on Tierra del Fuego Island compared to associated non-timber quality stands. J Insect Conserv 12:461-475

Lencinas MV, Martínez Pastur G, Cellini JM, Busso C (2012) Chapter 7. Improvement in conservation value of insect communities in South Patagonian forests managed with variable retention. In: Thangadurai $D$, Busso C, Abarca arenas L, Jayabalan S (eds) Frontiers in biodiversity studies. IK international publishing house, New Delhi, Bangalore, pp 118-130

Lencinas MV, Martínez Pastur G, Cellini JM, Gallo E, Busso C (2010) Diversidad de lepidópteros en bosques aprovechados: Variación en el corto plazo por aplicación de retención variable. Rev Inv Cient UNERMB 1(1):87-101

Lencinas MV, Martínez Pastur G, Gallo E, Cellini JM (2009) Alternative silvicultural practices with variable retention improve bird conservation in managed South Patagonian forests. For Ecol Manag 258:472-480

Lencinas MV, Martínez Pastur G, Gallo E, Cellini JM (2011) Alternative silvicultural practices with variable retention to improve understory plant diversity conservation in southern Patagonian forests. For Ecol Manag 262:1236-1250

Lencinas MV, Martínez Pastur G, Gallo E, Cellini JM (2014) Decreasing negative impacts of harvesting over insect communities using variable retention in southern Patagonian forests. J Insect Conserv 18:479-495

Lencinas MV, Martínez Pastur G, Medina M, Busso C (2005) Richness and density of birds in timber Nothofagus pumilio forests and their unproductive associated environments. Biodivers Conserv 14(10):2299-2320

Lencinas MV, Martínez Pastur G, Rivero P, Busso C (2008a) Conservation value of timber quality vs. associated non-timber quality stands for understory diversity in Nothofagus forests. Biodivers Conserv 17:2579-2597

Lencinas MV, Martínez Pastur G, Solán R, Gallo E, Cellini JM (2008c) Forest management with variable retention impact over moss communities of Nothofagus pumilio understory. Forstarchiv 79:77-82

Lencinas MV, Sola F, Martínez Pastur G (2017) Variable retention effects on vascular plants and beetles along a regional gradient in Nothofagus pumilio forests. For Ecol Manag 406:251-265

Lewandowski TE, Forrester JA, Mladenoff DJ, D'Amato AW, Fassnacht D, Padley E, Martin K (2019) Do biological legacies moderate the effects of forest harvesting on soil microbial community composition and soil respiration. For Ecol Manag 432:298-308

Lindenmayer D (1999) Future directions for biodiversity conservation in managed forests: indicator species, impact studies and monitoring programs. For Ecol Manag 115:277-287

Lindenmayer DB, Blair D, McBurney L (2019) Variable retention harvesting in Victoria's Mountain Ash (Eucalyptus regnans) forests (southeastern Australia). Ecol Proc 8:2

Lindenmayer DB, Franklin JF, Fischer J (2006) General management principles and a checklist of strategies to guide forest biodiversity conservation. Biol Conserv 131(3):433-445

Lindenmayer DB, Franklin JF, Lõhmus A, Baker S, Bauhus J, Beese W, Brodie A, Kiehl B, Kouki J, Martínez Pastur G, Messier C, Neyland M, Palik B, Sverdrup-Thygeson A, Volney J, Wayne A, Gustafsson L (2012) A major shift to the retention approach for forestry can help resolve some global forest sustainability issues. Conserv Let 5(6):421-431

Luque S, Martínez Pastur G, Echeverría C, Pacha MJ (2010) Chapter 15. Overview of biodiversity loss in South America: a landscape perspective for sustainable forest management and conservation in temperate forests. In: Li C, Lafortezza R, Chen J (eds) landscape ecology and Forest management: challenges and solutions in a changing globe. HEPspringer, Amsterdam, pp 352-379

Martínez Pastur G, Cellini JM, Lencinas MV, Barrera MD, Peri PL (2011b) Environmental variables influencing regeneration of Nothofagus pumilio in a system with combined aggregated and dispersed retention. For Ecol Manag 261:178-186

Martínez Pastur G, Cellini JM, Peri PL, Vukasovic R, Fernández MC (2000) Timber production of Nothofagus pumilio forests by a shelterwood system in Tierra del Fuego (Argentina). For Ecol Manag 134(1-3):153-162

Martínez Pastur G, Lencinas MV, Cellini JM, Peri PL, Soler R (2009) Timber management with variable retention in Nothofagus pumilio forests of Southern Patagonia. For Ecol Manag 258:436-443
Martínez Pastur G, Lencinas MV, Peri PL, Arena M (2007b) Photosynthetic plasticity of Nothofagus pumilio seedlings to light intensity and soil moisture. For Ecol Manag 243(2):274-282

Martínez Pastur G, Lencinas MV, Peri PL, Cellini JM (2008) Flowering and seeding patterns in unmanaged and managed Nothofagus pumilio forests with a silvicultural variable retention system. Forstarchiv 79:60-65

Martínez Pastur G, Lencinas MV, Peri PL, Moretto A, Cellini JM, Mormeneo I, Vukasovic R (2007a) Harvesting adaptation to biodiversity conservation in sawmill industry: technology innovation and monitoring program. J Tech Manage Innov 2(3):58-70

Martínez Pastur G, Peri PL, Cellini JM, Lencinas MV, Barrera MD, Ivancich H (2011a) Canopy structure analysis for estimating forest regeneration dynamics and growth in Nothofagus pumilio forests. Ann For Sci 68:587-594

Martínez Pastur G, Peri PL, Fernández MC, Staffieri G, Lencinas MV (2002) Changes in understory species diversity during the Nothofagus pumilio forest management cycle. J For Res 7(3):165-174

Martínez Pastur G, Peri PL, Lencinas MV, Cellini JM, Barrera MD, Soler R, Ivancich H, Mestre L, Moretto A, Anderson C, Pulido F (2013b) Chapter 8. La producción forestal y la conservación de la biodiversidad en los bosques de Nothofagus en Tierra del Fuego y Patagonia Sur. In: Donoso P, Promis A (eds) Silvicultura en bosques nativos: Avances en la investigación en Chile, Argentina y Nueva Zelanda. Universidad Austral de Chile, Valdivia, pp 155-179

Martínez Pastur G, Peri PL, Soler R, Schindler S, Lencinas MV (2016a) Biodiversity potential of Nothofagus forests in Tierra del Fuego (Argentina): tool proposal for regional conservation planning. Biodivers Conserv 25(10):1843-1862

Martínez Pastur G, Soler R, Cellini JM, Lencinas MV, Peri PL, Neyland M (2014) Survival and growth of Nothofagus pumilio seedlings under several microenvironments after variable retention harvesting in southern Patagonian forests. Ann For Sci 71:349-362

Martínez Pastur G, Soler R, Ivancich H, Lencinas MV, Bahamonde H, Peri PL (2016b) Effectiveness of fencing and hunting to control Lama guanicoe browsing damage: implications for Nothofagus pumilio regeneration in harvested forests. J Environ Manag 168:165-174

Martínez Pastur G, Soler R, Pulido F, Lencinas MV (2013a) Variable retention harvesting influences biotic and abiotic drivers along the reproductive cycle in southern Patagonian forests. For Ecol Manag 289(1):106-114

Massaccesi G, Roig F, Martínez Pastur G, Barrera MD (2008) Growth patterns of Nothofagus pumilio trees along altitudinal gradients in Tierra del Fuego, Argentina. Trees 22(2):245-255

Mitchell SJ, Beese WJ (2002) The retention system: reconciling variable retention with the principles of silvicultural systems. For Chron 78(3):397-403

New TR (2018) Forest management for insects: issues and approaches. In: New TR (ed) Forests and insect conservation in Aaustralia. Springer, Cham

Oro Castro N, Moretto A, Selzer L, Escobar J (2018) Effects of alternative silvicultural systems on litter decomposition and nutrients dynamics in subAntarctic forests. Agrofor Syst. https://doi.org/10.1007/s10457-018-0183-0

Perera A, Peterson U, Martínez Pastur G, Iverson L (2018) Ecosystem services from forest landscapes: Broadscale considerations. Springer, Cham, p 265

Peri PL, Gargaglione V, Martínez Pastur G (2008) Above and belowground nutrients storage and biomass accumulation in marginal Nothofagus antarctica forests in Southern Patagonia. For Ecol Manag 255(7):2502-2511

Peri PL, Lencinas MV, Bousson J, Lasagno R, Soler R, Bahamonde H, Martínez Pastur G (2016) Biodiversity and ecological long-term plots in Southern Patagonia to support sustainable land management: the case of PEBANPA network. J Nat Conserv 34:51-64

Peri PL, Martínez Pastur G, Lencinas MV (2009) Photosynthetic response to different light intensities and water status of two main Nothofagus species of southern Patagonian forest, Argentina. J For Sci 55(3):101-111

Peri PL, Martínez Pastur G, Monelos L (2013) Natural dynamics and thinning response of young lenga (Nothofagus pumilio) trees in secondary forests of Southern Patagonia. Bosque 34(3):273-279

Peri PL, Martínez Pastur G, Vukasovic R, Díaz B, Lencinas MV, Cellini JM (2002) Thinning schedules to reduce risk of windthrow in Nothofagus pumilio forests of Patagonia, Argentina. Bosque 23(2):19-28

Phalan B, Onial M, Balmford A, Green RE (2011) Reconciling food production and biodiversity conservation: land sharing and land sparing compared. Science 333:1289-1291

Rabassa J, Coronato A, Bujalesky G, Salemme M, Roig C, Meglioli A, Heusser C, Gordillo S, Roig F, Borromei A, Quattrocchio M (2000) Quaternary of Tierra del Fuego, southernmost South America: an updated review. Quater Inter 68-71:217-240 
Rebertus A, Kitzberger T, Veblen T, Roovers L (1997) Blowdown history and landscape patterns in the Andes of Tierra del Fuego (Argentina). Ecology 78(3):678-692

Simanonok MP, Anderson CB, Martínez Pastur G, Lencinas MV, Kennedy JH (2011) A comparison of impacts from silviculture practices and North American beaver invasion on stream benthic macroinvertebrate community structure and function in Nothofagus forests of Tierra del Fuego. For Ecol Manag 262(2):263-269

Sola FJ, Peri PL, Huertas L, Martínez Pastur G, Lencinas MV (2016) Above-ground arthropod community structure and influence of structural-retention management in southern Patagonian scrublands, Argentina. J Insect Conserv 20:929-944

Sola FJ, Valenzuela A, Anderson CB, Martínez Pastur G, Lencinas MV (2015) Reciente invasión del Archipiélago de Tierra del Fuego por la avispa Vespula germanica (Hymenoptera: Vespidae). Rev Soc Entom Arg 74(3-4):197-202

Soler R, Martínez Pastur G, Lencinas MV, Borrelli L (2012) Differential forage use between native and domestic herbivores in southern Patagonian Nothofagus forests. Agrofor Syst 85(3):397-409

Soler R, Martínez Pastur G, Lencinas MV, Moretto A, Peri PL (2011) Above- and below-ground nutrient tissue concentration and leaf pigment changes in Patagonian woody seedlings grown under light and soil moisture gradients. J Plant Nut 34:2222-2236

Soler R, Martínez Pastur G, Lencinas MV, Rosenfeld M (2014) Variable retention management influences biomass of Misodendrum and Usnea in Nothofagus pumilio southern Patagonian forests. NZ J Bot 52(2):224-235

Soler R, Schindler S, Lencinas MV, Peri PL, Martínez Pastur G (2015) Retention forestry in southern Patagonia: multiple environmental impacts and their temporal trends. Int For Rev 17(2):231-243

Soler R, Schindler S, Lencinas MV, Peri PL, Martínez Pastur G (2016) Why biodiversity increases after variable retention harvesting: a meta-analysis for southern Patagonian forests. For Ecol Manag 369:161-169

Soman H, Kizha AR, Roth BE (2019) Impacts of silvicultural prescriptions and implementation of best management practices on timber harvesting costs. Int J For Eng 30(1):14-25

Spagarino C, Martínez Pastur G, Peri PL (2001) Changes in Nothofagus pumilio forest biodiversity during the forest management cycle: insects. Biodivers Conserv 10(12):2077-2092

Tíscar PA (2019) Recruitment into the seedling bank of an undisturbed Mediterranean pinewood: increasing forest resistance to changing climates. For Ecol Manag 432:591-598

Tivoli A, Zangrando AF (2011) Subsistence variations and landscape use among maritime hunter-gatherers. A zoo-archaeological analysis from the Beagle Channel (Tierra del Fuego, Argentina). J Archaeol Sci 38:1148-1156

Torres AD, Cellini JM, Lencinas MV, Barrera MD, Soler R, Díaz-Delgado R, Martínez Pastur G (2015) Seed production and recruitment in primary and harvested Nothofagus pumilio forests: influence of regional climate and years after cuttings. For Syst 24(1):e-016

Vergara PM, Schlatter R (2006) Aggregate retention in two Tierra del Fuego Nothofagus forests: short-term effects on bird abundance. For Ecol Manag 225(1-3):213-224

Wagner S, Collet C, Madsen P, Nakashizuka T, Nyland R, Sagheb-Talebi K (2010) Beech regeneration research: from ecological to silvicultural aspects. For Ecol Manag 259:2172-2182

\section{Submit your manuscript to a SpringerOpen ${ }^{\circ}$ journal and benefit from:}

- Convenient online submission

- Rigorous peer review

- Open access: articles freely available online

- High visibility within the field

- Retaining the copyright to your article

Submit your next manuscript at $>$ springeropen.com 